\title{
Ontario fee cuts enrage nation's doctors
}

$\mathrm{S}$ olidarity forever, as the adage goes, even for the nation's doctors.

Fearing that the government of Ontario's recent unilateral changes in the fee schedules of its physicians is an indicator of future moves by other provinces to limit collective bargaining rights, Canada's doctors ratcheted the rhetoric and voted to have their national association press for an amendment to the Canada Health Act to legally guarantee binding contracts and binding arbitration by a panel with an "independent chairman" in the event of contract disputes.

Delegates to the 145th annual general meeting of the Canadian Medical Association, held in Yellowknife, Northwest Territories, also compelled the national body to "support any provincial/territorial association in a court challenge to a refusal by their provincial/territorial government to participate in a fair bargaining process."

Ontario's doctors have filed a suit in the Ontario Supreme Court charging that their provincial government breached their right to negotiate in good faith under Canada's Charter of Rights and Freedoms when it announced changes to its fee schedule for clinicians after claiming that negotiations had broken down with the Ontario Medical Association (OMA) over how best to implement a wage freeze. Among those changes were a $50 \%$ reduction in payments for self-referrals, an $11 \%$ reduction in fees paid for diagnostic radiology tests and a $\$ 42.25$ cut, to $\$ 397.75$, in the fee paid for cataract surgery (http://news.ontario.ca/mohltc/en/2012 /05/ontario-freezing-doctor-pay-to-invest -in-more-community-care-for-families -and-seniors.html).

Although labour matters are not typically the purview of CMA, delegates, led by the presidents of provincial and territorial medical associations, all but lined-up at the microphones to express outrage at the Ontario government move, and to urge the nation's doctors

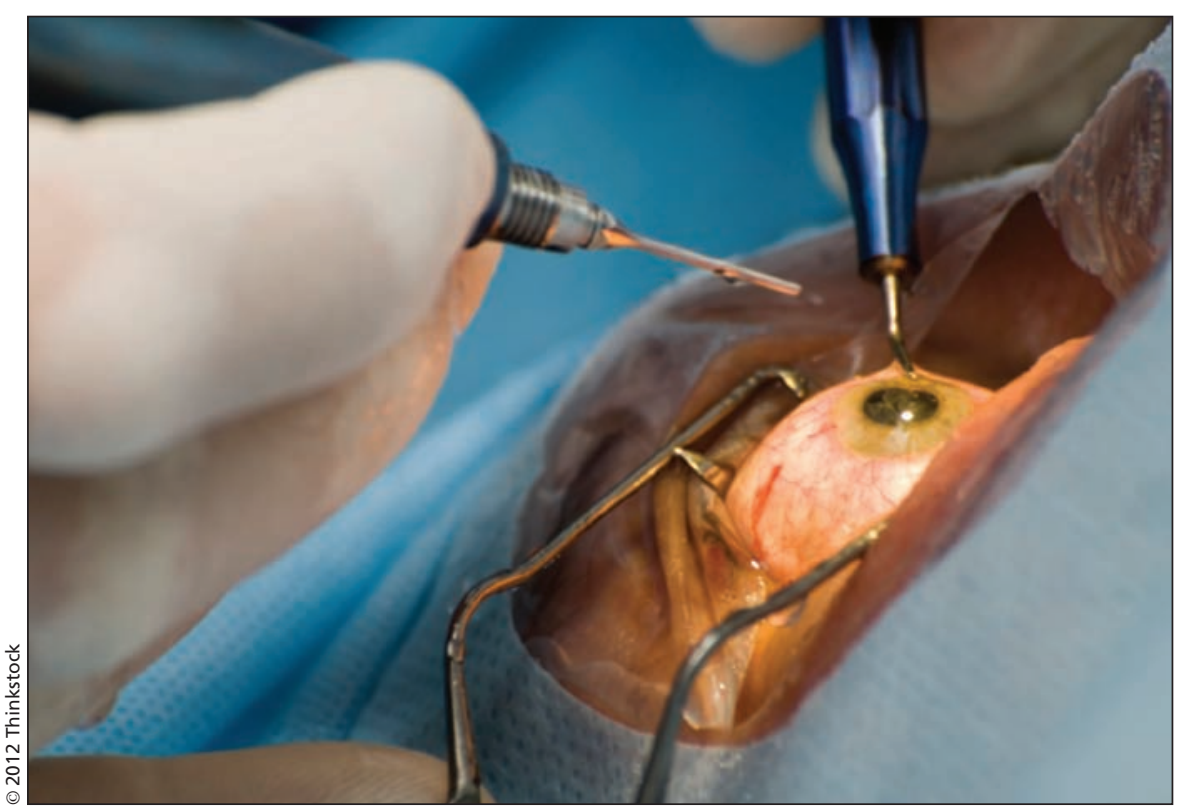

Recent changes to the fee schedule for clinicians in Ontario, including a $\$ 42.25$ cut for cataract surgery, have Canadian doctors seeing red.

to "stand united as a profession," as British Columbia Medical Association President Dr. Shelley Ross put it.

Fear that other provinces might follow Ontario's lead clearly loomed large in the minds of many delegates.

"It's an issue that is going to be coming up across the country," said Dr. Robert Rae, president of the New Brunswick Medical Society, adding that doctors in his province are "concerned that what is happening now in Ontario may spread across the country."

OMA President Dr. Doug Weir indicated that Ontario's doctors will expend every effort, and any needed dollars, in defence of the principle of collective bargaining. "If need be, we will go to the Supreme Court" of Canada.

Alberta Medical Association President Dr. Linda Slocombe said her provincial government is already "taking lessons from the Ontario health minister," while several delegates contended that the reputation of doctors was being assailed by the Ontario government's assertions that physicians are driven by greed, rather than any measure of idealism.
"It's essential that governments respect us," argued Dr. Anna Reid, who'll today assume CMA's helm. "If this strategy continues, then it will deeply divide us, pitting physician groups against each other."

Others raised the spectres of physician bankruptcy, ailing patients left to their own devices and even compulsory medical service. "My colleagues, it's starting to look like conscription," argued Dr. Stanley Lofsky of Toronto, Ontario.

Dr. Robert Woollard, board member of Canadian Doctors for Medicare and professor of family medicine at the University of British Columbia in Vancouver, later told reporters that history doesn't support the Ontario government's decision to impose unilateral changes in fee schedules. "Let's go back to the evidence. Evidence, historically and elsewhere, is that reluctant conscripts never give you your best output. So even if I was an industrialist and even if I was completely imbued with the importance and the singularity of capitalism as a way of doing things, it's just stupid public policy to get yourself into that situation." 
Outgoing Canadian Medical Association President Dr. John Haggie later told a press conference that the Ontario government's "confrontational" approach is "somewhat counterproductive. The change experts will tell you that if you want to change a system for the better, it has to be done in a collaborative, negotiated way and you can't impose by dictat from the top."

As to the nature of the support to be provided to the OMA, Haggie said that's "contingent on what the Ontario Medical Association feel they need and we'll work that out over the coming weeks."

The nation's physicians were far less united with respect to a separate resolution calling on CMA to "encourage family physicians to maintain a strong foothold in comprehensive family medicine when developing focused areas of practice." The fireworks immediately started flying. Several delegates expressed incredulity that anyone would seek to put limits on the scope of their practices in a manner that no one would contemplate imposing on a specialist.

Others took affront at the implication that a family physician with a focused practice would neglect duties to a patient because they were consumed with, for example, psychiatric or pediatric matters. Proponents argued that the intent of the motion wasn't to curb the trend towards focused family practices, but rather to ensure that the trend didn't squeeze the pool of available family physicians with comprehensive practices. The motion was defeated by a narrow 106-100 count.

Among motions adopted was a call for the creation of a database owned and managed by doctors to "facilitate Canadian physicians' objective selfassessment," as well as approval of a $\$ 20$-increase in the CMA membership fee to $\$ 450$ per year. - Wayne Kondro, $C M A J$

CMAJ 2012. DOI:10.1503/cmaj.109-4272 